\title{
Pain Intensity on School-Age Children Through Intravenous Insertion with Peppermint Aromatherapy as Intervention Method at Pediatric Room Rsud Ulin Banjarmasin
}

\author{
Malisa Ariani ${ }^{1}$, Yayat Suryati ${ }^{2}$, Rini Mulyati ${ }^{3}$ \\ \{malisaariani@unism.ac.id\} \\ Sari Mulia University, Jl. Scout 2, Pemurus Affairs. District. East Banjarmasin, Banjarmasin, \\ South Kalimantan, 70 238, Indonesia ${ }^{1}$, STIKES Jend. A. Yani Cimahi ${ }^{2}$, \\ STIKES Jend. A. Yani Cimahi ${ }^{3}$
}

\begin{abstract}
Intravenous therapy is one of procedure that may cause pain and can be a problem on children during hospitalization. Aromatherapy is one of non-pharmacological method that is easy to do to help decreasing or reducing the pain. This study aims to describe of children pain intensity when they have intravenous insertion using peppermint aromatherapy intervention and no intervention. This research is quantitative and descriptive design. There are 24 children as the participants by using purposive sampling technique. The data is collected using Wong Baker Faces Pain Rating Scale. The result of this study showed the mean of pain intensity in intervention group was 2,17 and 4,08 in non-intervention group. Inhalation aromatherapy using peppermint essence has helped to reduce the pain intensity in school-age children during intravenous insertion.
\end{abstract}

Keyword: Peppermint aromatheraphy, school-age children, pain intensity, intravenous insertion

\section{Introduction}

Childhood is a very pleasant time and filled with a variety of new things. However in reality, not all children have a good time, children can also experience pain that makes them have to be treated at hospital [19]. When a child is sick and requires him to be hospitalized, of course it could be a major stressor that must be faced by children. Various stressors that can be experienced by children when hospitalized, among others, are caused by an unfamiliar environment, different habits, loss of control, separation from family and the emergence of bodily injury and pain due to actions taken [16], [26]. When the child is hospitalized, certainly the child will get a variety of procedures that can cause pain, so that the preparation and explanation is needed for the child so that the child is able to prepare himself for the pain he is experiencing in order to avoid anxiety, fear and stress [5], [13], [25].

El-Gawad \& Elsayed (2015) in his study explaining the action of invasive procedures is one of the main sources of pain that is often performed in children [11]. Research from 
Steven, et al., (2012 in Carter \& Simons, 2014), in children $(\mathrm{n}=3822$ people) treated at eight different Children's Hospitals in Canada, found that within 24 hours of the study, there were \pm 18 procedures recorded, and $87 \%$ of children experience one or more painful procedures [8]. Harrison's, et al (2014) states that children experience moderate to severe pain around $82 \%$ while undergoing hospitalization due to invasive medical procedures. Therefore, children are very worried and disturbed by invasive medical procedures [7], [12]. While the Walco study (2008) explains the prevalence of pain and the main source of pain in 200 children who are hospitalized. The results of IV (intravenous) medical procedures occupy the first step as triggers that cause pain.

Nurses need to do the assessment of pain in children before, during and after treatment to overcome the pain given. Accuracy in assessing pain experienced by children is important to see the effect of pain management that will be done [2]. According to Wong, et al (2009), efforts to overcome the pain experienced by children can be done by applying pharmacological and nonpharmacological pain management. Nurses as a profession that carries out the care for their patients, have the authority and responsibility for nonpharmacological therapy to provide interventions to relieve or reduce pain in order to provide comfort to their clients. Non-pharmacological actions are also procedures that can be performed independently by nurses without waiting for instructions from the doctors [14].

There are various kinds of non-pharmacological procedures that can be done to reduce pain such as image guidance, distractions, hypnosis, relaxation techniques, breathing control, and biofeedback exercises [23]. Andrew (2009) states that relaxation techniques can be done in various ways, one of which is aromatherapy treatment. Aromatherapy is one of the complementary therapies to reduce pain that can be done by nurses.

Peppermint aromatherapy has a content of menthol and methyl salicylate as an active ingredient to major manufacture of peppermint essence. Based on several studies, peppermint essence has a scent that refreshes and have many effects such as an anti-spasmodic, antiinflammatory, anti-viral, anti-septic, can cure the problem of disease bronchitis and cough, fatigue, headache/ migraine and disorders tract digestibility. In addition, peppermint essence also has efficacy as an analgesic that is strong (the pain-killer) through the kappa-opioid receptor activation, which can help block the transmission of pain signals [1], [6], [22]. The use of aromatherapy can be given by some ways such as inhalation, bathing, massage and compress. Access through the nose (inhalation) is a treatment that is much quicker than the other way [3], [15].

The results of the observation of researchers in the preliminary study show that when intravenous insertion is obtained to the two preschool children, they reacted to the pain when the injection is being done. The reacts were crying, screaming and attempted pull his hand, while the two preschool children react to injection such cry and grimace as he strongly clench his fist but still braced himself for being injected. Results of interviews were conducted to the head of the Pediatric Room at Ulin Hospital Banjarmasin states that they usually do the procedures for the management of pain before or when they do the intravenous insertion which is often applied to all subjects that divert attention by inviting children to chat or play. For children who cooperate may advisable also to carry out the techniques of relaxation breath in time to do the invasive procedure as the management of pain non-pharmacological. But related to the administration of aromatherapy for the management of pain non- 
pharmacologic on children when performed intravenous insertion has not been applied to all subjects.

\section{Methods}

This research is quantitative and descriptive design. Samples were collected by the technique of purposive sampling. The total sample of 12 respondents for the intervention group (given aromatherapy treatment) and 12 respondents for the control group (not given aromatherapy treatment) were obtained based on calculations with criteria for children aged 6-12 years, children who were first put on the infusion, in full conscious condition, good olfactory function, does not have a history of allergy smelt odors. Instruments of research that is used to measure the intensity of pain when done the catheter injection with Wong Baker Faces Pain Rating Scale. This research has passed the feasibility test of research ethics at Ulin Hospital Banjarmasin with no. 048/ V-Reg Research/ RSUDU/ 17.

The procedure in the research is done by giving aromatherapy treatment on interventions group and not given any treatment on the control group. Giving aromatherapy treatment on a group of interventions carried out by inhalation and the type of aromatherapy that is used is aromatherapy peppermint. Respondents who are willing to get the treatment are then taken to the action room. The patient is positioned as comfortable as well as when the procedure insertion of the infusion is done. After the researchers dripped oil peppermint aromatherapy as much as 3 drops on a screen measuring $10 \times 10 \mathrm{~cm}$ (given and instilled five minutes prior to the insertion of the cannula). Then, gauze at shirt collar or children were told to hold it with a distance of 7-10 $\mathrm{cm}$ while children are encouraged to breathe in the aromatherapy. Aromatherapy will be given 5 minutes before and continued during the installation of the infusion is done. Immediately after the injection of cannula, then directly measured the intensity of the pain that is experienced by the child. If the first trial fails, then the respondent will be eliminated from the study.

\section{Result}

Implementation research starts from the licensing and the research has been done on May $10^{\text {th }}$ to July $24^{\text {th }} 2017$. The presentation of the results of the analysis of univariate in the study is comprised of picture characteristics of the demographics of respondents that are age, type of sex and tribes as well as a variable dependent that are the intensity of the pain of respondents in the group intervention (given aromatherapy) and the control group (not given aromatherapy). 


\subsection{Overview Characteristics of Respondents}

Table 1. Distribution of Frequency of Respondents by Age of the Child, Type of Sex, and Tribes in Pediatric Room at Ulin Hospital Banjarmasin May - July 2017 (N = 24)

\begin{tabular}{|c|c|c|c|c|c|}
\hline \multicolumn{2}{|c|}{$\begin{array}{l}\text { Characteristics of } \\
\text { Respondents }\end{array}$} & \multicolumn{2}{|c|}{$\begin{array}{l}\text { The group was } \\
\text { treated } \\
\text { aromatherapy } \\
(\mathrm{n}=12)\end{array}$} & \multicolumn{2}{|c|}{$\begin{array}{c}\text { The group was not } \\
\text { treated } \\
\text { aromatherapy } \\
(\mathrm{n}=12)\end{array}$} \\
\hline & & $\mathbf{F}$ & $\%$ & $\mathbf{F}$ & $\%$ \\
\hline \multirow{7}{*}{$\begin{array}{l}\text { Age of the } \\
\text { children }\end{array}$} & 6 years old & 3 & 25 & 3 & 25 \\
\hline & 7 years old & 1 & 8,3 & 1 & 8,3 \\
\hline & 8 years old & 1 & 8,3 & 2 & 16,7 \\
\hline & 9 years old & 0 & 0 & 0 & 0 \\
\hline & 10 years old & 3 & 25 & 1 & 8,3 \\
\hline & 11 years old & 2 & 16,7 & 3 & 25 \\
\hline & 12 years old & 2 & 16,7 & 2 & 16,7 \\
\hline \multirow{2}{*}{$\begin{array}{c}\text { Type of } \\
\text { Sex }\end{array}$} & Male & 7 & 58,3 & 8 & 66,7 \\
\hline & Female & 5 & 41,7 & 4 & 33,3 \\
\hline \multirow{3}{*}{ Tribes } & Banjar & 8 & 66,7 & 10 & 83,3 \\
\hline & Dayak & 3 & 25 & 0 & 0 \\
\hline & Jawa & 1 & 8,3 & 2 & 16,7 \\
\hline
\end{tabular}

Based on Table 1 above shows that the age of the respondents most in the group were given aromatherapy treatment are aged 6 years old and 10 years old, respectively numbered as many as 3 people (25\%), while the group that was not given aromatherapy. The age of the respondents the most is the age of 6 years old and 11 years old, respectively numbered as many as 3 people (25\%). For the type of sex, male are most dominant in the two groups. Number of respondents by type of sex male in the group given aromatherapy is numbered 7 (58.3\%) and the group not given aromatherapy are total to $8(66.7 \%)$. As for the ribes groups, the majority of respondents in both groups come from the Banjar tribe group. The number of respondents who come from the Banjar tribe in the group given aromatherapy as many as eight people (66.7\%) and in the group not given aromatherapy as many as 10 people (83.3\%). 


\subsection{Overview of Intervention Group Pain Intensity}

Tabel 2. Overview of Pain Intensity in the Intervention Group in the Pediatric Room at Ulin Hospital Banjarmasin May - July $2017(\mathrm{~N}=12)$

\begin{tabular}{|c|c|c|c|c|c|c|c|c|c|c|c|c|c|c|c|}
\hline \multicolumn{16}{|c|}{ Group given Aromatherapy } \\
\hline \multirow{3}{*}{$\begin{array}{c}\text { Mean } \\
\text { Median }\end{array}$} & \multirow{3}{*}{ SD } & \multirow{3}{*}{$\begin{array}{l}\text { Min- } \\
\text { Max }\end{array}$} & \multirow{3}{*}{$\begin{array}{c}95 \% \\
\text { CI }\end{array}$} & \multicolumn{12}{|c|}{ Pain Intensity } \\
\hline & & & & \multicolumn{2}{|c|}{$\mathbf{0}$} & \multicolumn{2}{|c|}{1} & \multicolumn{2}{|c|}{2} & \multicolumn{2}{|c|}{3} & \multicolumn{2}{|c|}{4} & \multicolumn{2}{|c|}{5} \\
\hline & & & & $\mathbf{F}$ & $\%$ & $\mathbf{F}$ & $\%$ & $\mathbf{F}$ & $\%$ & $\mathbf{F}$ & $\%$ & $\mathbf{f}$ & $\%$ & $\mathbf{f}$ & $\%$ \\
\hline 2,17 & 0,718 & $1-3$ & $1,71-$ & 0 & 0 & 2 & 16,7 & 6 & 50 & 4 & 33,3 & 0 & 0 & 0 & 0 \\
\hline 2,00 & & & 2,62 & & & & & & & & & & & & \\
\hline
\end{tabular}

Based on table 2, it can be seen that the results of the distribution of pain intensity in the group given aromatherapy treatment obtained an average of children's pain of 2.17. Obtained 2 respondents $(16.7 \%)$ with a pain scale of 1 (delicate pain), 6 respondents $(50 \%)$ with a pain scale of 2 (mild pain), 4 respondents $(33.3 \%)$ with pain scale 3 (stronger pain).

\subsection{Overview of Control Group Pain Intensity}

Tabel 3. Overview of Pain Intensity in the Control Group in the Pediatric Room at Ulin Hospital Banjarmasin May - July 2017 ( N = 12)

\begin{tabular}{|c|c|c|c|c|c|c|c|c|c|c|c|c|c|c|c|}
\hline \multicolumn{16}{|c|}{ Group not given Aromatherapy } \\
\hline \multirow{3}{*}{$\begin{array}{l}\text { Mean } \\
\text { Median }\end{array}$} & \multirow{3}{*}{ SD } & \multirow{3}{*}{$\begin{array}{l}\text { Min- } \\
\text { Max }\end{array}$} & \multirow{3}{*}{$\begin{array}{c}95 \% \\
\text { CI }\end{array}$} & \multicolumn{12}{|c|}{ Pain intensity } \\
\hline & & & & \multicolumn{2}{|c|}{$\mathbf{0}$} & \multicolumn{2}{|c|}{1} & \multicolumn{2}{|c|}{2} & \multicolumn{2}{|r|}{3} & \multicolumn{2}{|r|}{4} & \multicolumn{2}{|c|}{5} \\
\hline & & & & $\mathbf{F}$ & $\%$ & $\mathbf{F}$ & $\%$ & $\mathbf{F}$ & $\%$ & $\mathbf{F}$ & $\%$ & $\mathbf{F}$ & $\%$ & $\mathbf{f}$ & $\%$ \\
\hline $\begin{array}{l}4,08 \\
4,00\end{array}$ & 0,669 & $3-5$ & $\begin{array}{c}3,66- \\
4,51\end{array}$ & 0 & 0 & 0 & 0 & 0 & 0 & 2 & 16,7 & 7 & 58,3 & 3 & 25 \\
\hline
\end{tabular}

Based on Table 3, can be seen that the result of the distribution of the intensity of pain in the group that was not given aromatherapy treatment obtained an average pain of children at 4.08. Obtained 2 respondents (16.7\%) with pain scale 3 (stronger pain), 7 respondents $(58.3 \%)$ with a pain scale of 4 (strongest pain), 3 respondents $(25 \%)$ with a pain scale of 5 (awful worst pain).

\section{Discussion}

Wong, et al (2009), a lot of factors that can affect the perception of a person to vote intensity of pain that is felt. The intensity of pain that are experienced by children in the two groups of these possibilities can also be influenced by several factors among others age of the 
child and the type of sex [26]. Daniela, et al (2010) explained that the different levels of development in the age group of children can affect children reacting to pain. According to Wong, et al (2009), children in the school-age is able to communicate in verbal pain that they are naturally associated with the location, intensity and the description [10]. Prasetyo (2010) argues that age is an important variable in influencing pain in individuals. Children that are still small have difficulty in understanding the pain and the procedures that can lead to the onset of pain, and they are also still difficult to reveal verbal words. The level of development of the child will be synchronized with the increase of age, so that the tolerance to pain will increase if age is also getting increased [21] .

In addition to age, which can affect the intensity of the pain is the type of sex. According to Potter \& Perry (2009), in general does not exist differences in response to pain between men and women, however some cultures do not allow men to cry and to be courageous against pain while women may cry in a situation that is similar [20]. Kyle \& Carman (2015) explains also that the children of men, and children of women have different in how they accept and cope with the pain and respond to analgesic. It may be affected by various factors among others genetic, hormonal, family and culture [16].

The nurse as a profession whom care to patients, has the authority and responsibility in charge of the implementation of the management of pain non-pharmacologic as an intervention method to help reducing the pain when children encounter invasive procedures that is one of the only installation of the infusion (intravenous insertion). There are various kinds of non-pharmacological actions that can be performed on children, one of them is giving aromatherapy treatment. Trail-Mahan, et al (2013) and Andrew (2009) explains that aromatherapy is one of the types of therapies complementary which is part of the method of non-pharmacological which can be done by nurses [24].

Koensoemardiyah (2009) defines aromatherapy as the administration of essential oils through methods of massage, inhalation, bathing, compressing or topical ointment [15]. Research from Boehm, Bussing \& Ostermann (2012) explained that the use of aromatherapy has many advantages such as overcoming pain, anxiety, depression, tension muscles, sleep disorders, fatigue and nausea [4]. Research of Lakhan, Sheafer \& Tepper (2016) states that aromatherapy can help reduce pain in a variety of conditions such as lowering the pain of chronic, post-surgery pain, the pain of labor, pain in children, pain due to disease failed kidney and the pain of cancer [17].

Research from Ali, et al (2015) showed that aromatherapy peppermint has a content of a substance analgesic [1]. Theory of Culbert \& Olness (2010) states that the mechanism of analgesia of peppermint aromatherapy associated with modulation of the perception of the taste of pain that inhibits impulses nociceptors or by activating the system of endogenous opioids that can suppress the impulse of pain so the pain is not to be forwarded to the brain, in conclussion the lower the perception of pain [9]. Lv , et al (2013) explains that the effect of aromatherapy begins when the scent is inhaled through the nose (inhalation), then the molecules aroma turns into a signal of nerve in the olfactory bulb, amygdala, and the system limbic and produce effects therapeutic by causing the release of various kinds of neurotransmitters such as encephalin, endorphins and serotonin so that it directly affects the olfactory organ and is perceived by the brain to give reactions that make changes to the body, mind, soul and produce pleasant effects and can reduce pain perception [18]. 
Based on short interviews during the study, several intervention to the group respondents revealed that when given peppermint aromatherapy treatment, it can make them feel comfortable and smell refreshing like the smell of gum. In order to reduce the pain of the needle (insertion) when the procedure of infusion, it can be done giving aromatherapy peppermint by inhalation before and during the installation of the infusion (intravenous insertion) is done. In this study, researchers assumed that the importance of complementary therapy using peppermint aromatherapy treatment as a non-pharmacological pain management is useful to help reduce pain during the procedure and is expected to improve children's conveniences.

\section{Conclusion And Recommendation}

\subsection{Conclusions}

a. The average intensity scale of pain the child after intravenous insertion in group intervention were given peppermint aromatherapy treatment is 2.17 with many numbers of respondents experienced pain scale 2 (delicate pain) of 6 respondents $(50 \%)$.

b. The average intensity scale of pain the child after intravenous insertion in group control are not given aromatherapy peppermint treatment is 4.08 with many numbers of respondents experiencing pain scale of 4 (strongest pain) by 7 respondents $(58.3 \%)$.

\subsection{Suggestions}

Other researchers can conduct the study on the provision of aromatherapy treatment with various fragrance and techniques that are different and associated with other more diverse variables.

\section{Acknowledgements}

A warm gratitude to Ulin Hospital Banjarmasin which has been given permission, opportunity and assist the researcher to conduct the study. Special gratitude also to all respondents who had been willing to be voluntary respondent of our study.

\section{References}

[1] Ali, B., et al. Essential Oil Used Aromatherapy: A Systematic Review. Asian Pac J Trop Biomed. 5(8). pp. $601-611$. (2015).

[2] Berman, A. \& Snyder, S. Kozier and Erb's Fundamentals of Nursing: Concepts. Process and Practice ( $9^{\text {th }}$ edition). USA: Pearson. (2012).

[3] Bharkatiya, M., et al. Aromatheraphy: Short Overview. International Journal of Green Pharmacy. 2(1). pp. 13 - 16. (2008).

[4] Boehm, K., Bussing, A., \& Ostermann, T. Aromatherapy as An Adjuvant Treatment in Cancer Care - A Descriptive Systematic Review. African Journal of Traditional. Complementary and Alternative Medicines. 9(4). pp. 503 - 518. (2012).

[5] Canbulat, Inal, \& Sonmezer. Efficacy of Distraction Methods on Procedural Pain and Anxiety by Applying Distraction Cards and Kaleidoscope in Children. Asian Nursing Research 8. pp. 23-28. (2012). 
[6] Cappello, G., et al. Peppermint Oil (Mintoil) in The Treatment of Irritable Bowel Syndrome: A Prospective Double Blind Placebo Controlled Randomized Trial. Dig Liver Dis. 39. pp. 530536. (2007).

[7] Caprili, S., et al. Pain and Distress in Children Undergoing Blood Sampling: Effectiveness of Distraction with Soap Bubbles. Giornale Italiano di Science Infermieristiche Pediatriche. 4(1). pp. 15 - 18. (2012).

[8] Carter, B., \& Simon, J. Stories of Children's Pain: Linking Evidence to Practice. London: SAGE. (2014).

[9] Culbert, T. P., \& Olness, K. Integrative Pediatrics. New York: Oxford University Press. (2014).

[10] Daniela, M., et al. Physiology of Pain - General Mechanisms and Individual Differences. Jurnal Medical Aradean. 8(4). pp. 19 - 23. (2010).

[11] El-Gawad, S. M. E., \& Elsayed, L. A. Effect of Interactive Distraction Versus Cutaneous Stimulation for Venipuncture Pain Relief in School Age Children. Journal of Nursing Education and Practice. 5(4). pp. 32-40. (2015).

[12] Harrison, D., et al. Pain Prevalence in A Pediatric Hospital: Raising Awareness During Pain Awareness Week. Pain Research and Management. 19(1). pp. e24 - e30. (2014).

[13] Hockenberry, M. J., \& Wilson, D. Essential of Pediatric Nursing. St. Louis: Mosby Year Book. (2009).

[14] Kashanina, Z., et al. The Effect of Cangaroo Care on Behavioral Responses to Pain of Intramuscular Injections in Neonates. Journal of Specialist in Pediatric Nursing. 13(4). pp. 275 - 280. (2009)

[15] Koensoemardiyah. A-Z Aromaterapi untuk Kesehatan, Kebugaran dan Kecantikan. Yogyakarta: Lily Publisher. (2009).

[16] Kyle, T., \& Carman, S. Buku Ajar Keperawatan Pediatri Edisi 2. Jakarta: EGC. (2015).

[17] Lakhan, S. E., Sheafer, H., \& Tepper, D. The Effectiveness of Aromatherapy in Reducing Pain: A Systematic Review and Meta-Analysis. Pain Research and Treatment. pp. 1 - 13. (2016).

[18] Lv, X. N., et al. Aromatherapy and The Central Nerve System (CNS): Therapeutic Mechanism and Its Associated Genes. Curr. Drug Targets. 14(8). pp. 872 - 879. (2013).

[19] Pieter, H.Z., Janiwarti, B., \& Saragih. Pengantar Psikopatologi untuk Keperawatan. Jakarta: Kencana. (2011).

[20] Potter, A. P., \& Perry, G. A. Buku Ajar Fundamental Keperawatan: Konsep, Proses, dan Praktik Edisi 7. Jakarta: EGC. (2009).

[21] Prasetyo, S. N. Konsep dan Proses Keperawatan Nyeri. Yogyakarta: Graha Ilmu. (2010).

[22] Rahnama, P., et al. Rhizomes (Ginger) on Pain Relief in Primary Dysmenorrhea: A Placebo Randomized Trial. BMC Complementary and Alternative Medicine. 12(1). pp. 92. (2012).

[23] Srouji, R., Ratnapalan, S., \& Schneeweiss. Pain in Children: Assessment and Nonpharmacological Management. International Journal of Pediatrics. 474(11). pp. 838 - 842. (2010).

[24] Trail-Mahan, T., Mao, C. L., Bawel-Brinkley, K. Complementary and Alternative Medicine: Nurse' Attitudes and Knowledge. Pain Manag. Nurs. 14(4). pp. 277 - 286. (2013).

[25] Truba, N., \& Hoyle, J. D. Pediatric Pain. Journal of Pain Management. 7(3). pp. 235 - 248. (2014).

[26] Wong, D. L., et al. Buku Ajar Keperawatan Pediatrik. Edisi 6. Jakarta: EGC. (2009) 